through the tissues. The knife was only used three times. I had no difficulty in reaching the bladder and in extracting the stone, which was, as I had supposed, encysted, and not to be easily discovered ; in fact, I at first thought there was no stone, as only a very small surface could be felt, and requiring some little manipulation to free it from its cyst walls. A drainage-tube was passed from the external wound through the urethra, and left in, situ about tive days. The patient has made an uninterrupted recovery, and is now (July 26th) passing all his urine by the urethra, and the wound is nearly healed. The operation was attended by very little hæmorrhage, all veins being held aside, and was much easier to perform than the perineal operation. The stone is about an inch long, half an inch broad, and weighs one drachm five grains.

I place this case upon record as the high operation is only recommended for large calculi ; but in all cases of encysted calculi I strongly advise it, and believe it the best resource. Baschurch.

\section{LARGE BURNS.}

BY T. SOMERVILLE SMith, M.D.

ON February 25th C. W- aged three years and six months, being left alone in the kitchen, played with the fire, burning himself in a dreadful manner. I saw him half an hour after the accident, and found him in a state of collapse, suffering from shock. The extent of the burns, subsequently ascertained, was as follows:-

All over the abdomen, width five inches, length seven; down the left thigh, width three inches, length four; on the back, nine inches long and four wide ; round each arm, three inches long and four wide; round the neck, three inches long and three wide. The true skin was burnt through over the whole of the abdomen and a portion of the back. Linen rags steeped in linseed oil and lime water were applied to the burnt surfaces. Purgatives, at first administered, were discontinued, as peritonitis set in, accompanied for nearly a whole day with suppression of urine. The child lay on its back with its legs drawn up, the bowels not beir $-r$ relieved for eight days. There was delirium at night fo the first five or six days. The treatment was as follows : Brandy during collapse, with bark and ammonia ; bromide of potash for rest at night. Linseed oil and lime water were continued for about a week, at the end of which linseed poultices, with plenty of linseed oil in them, were applied to the abdomen and part of the back to remove the eschars. When the wounds were perfectly clean the whole of the raw surfaces were smeared with an ointment composed of lard, zinc, and glycerine, under which they slowly but surely healed. The child's strength was kept up by tonics. There is a very slight contraction in the left groin, where the thigh and abdomen wounds meet; in all other respects the child is now convalescent.

Sittingbourne.

\section{di fitlirtor} of

\section{HOSPITAL PRACTICE, BRITISH AND FOREIGN.}

Nulla autem est alia pro certo noscendi via, nisi quamplurimas et mor. borum et dissectionum historias, tum aliorum tum proprias collectas habere, et inter se comparare.-Morgagni De Sed. et Caus. Morb., lib. iv. Procmium.

\section{ST. THOMAS'S HOSPITAL.}

CASES OF ORBITAL, CELLULTTIS AND ORTETAL ABSCESS; REMARKS.

(Under the care of Mr. J. B. LAwFoRD, Assistant Ophthalmic Surgeon.)

THESE cases, which are examples of inflammation of the cellular tissue of the orbit, some of which terminated in abscess, illustrate the difficulty often met with in tracing a disease to a definite cause, as well as the successful treatment of a serious condition. In no case was any history of injury obtained, and in only one was disease of the bony wall of the orbit found, making it probable that the suppuration in the orbit was secondary to a localised periostitis. There had been no recent attack of fever or erysipelas, but in Case 4 renal disease was present, the patients were apparently free from evidence of visceral disease. Mr. Lawson speaks of an acute inflammatory exudation into the orbit of a syphilitic nature presenting the characters of a cancerous growth, and considers that some of the firm orbital tumours which had gradually subsided under treatment may have been of this nature. To show the remarkable resemblance, he cites a case in which he was himself misled by this close resemblance to malignant disease. When unable to account satisfactorily for the onset of an inflammation, it is not infrequent to find it ascribed to a chill, and this observation applies equally to orbital cellulitis as to inflammations in other parts of the body. Day ${ }^{3}$ described a case of acute exophthalmos. After exposure to cold rain the eye protruded nearly three-quarters of an inch, the pupil being dilated. The protrusion of the eye subsided only after two months, without suppura. tion in the orbit, and vision continued unimpaired. The fundus was not examined. He ascribed the condition to congestion of the vessels, and perhaps infiltration of serum or blood in the post-orbital tissues. There was apparently nothing to cause the disease excepting the exposure to cold. The subjects of orbital cellulitis and abscess are so frequently depressed and feeble that it is quite possible sudden changes of temperature may lead to a localised venous thrombosis, with a secondary inflammation of the tissues around. The disease may be part of a pyamic infection of the system, and is occasionally found accompanying the puerperal state. It may be secondary to abscess of the lacrymal gland. The disease may prove fatal by extension of the inflammation backwards to the cerebral membranes, but this is not a frequent sequence. Much more commonly the result of the disease is shown in more or less complete loss of vision in the eye of the affected side, by stretching of, or pressure on, the optic nerve; ulceration of the cornea may also occur from damage to the ciliary nerves belind the globe. ${ }^{3}$ As regards prognosis, much will depend upon the period in the course of the disease at which treatment is commenced and the way in which it is carried out, as well as upon the causation of the disease.

CASE 1. (From notes by Mr. Hinnell.)-Charles Daged thirteen, a schoolboy, was admitted on Aug 25th, 1886 . The illness began on the 15th, when the boy awoke at night with severe pain in and about the right eye. The lids were then noticed to be swollen. The pain has continued since, and there has been frequent vomiting. There is no history of injury, or of recent illness. Family history unimportant.

On admission, there was marked proptosis of the right eye, the globe being protruded to the outer side of the middle line; almost fixed, but a little outward movement retained. There was slight bluish discolouration of the lids, with very little swelling. The cornea were clear, the pupil equalled the left in size and reaction. $V=J . l$. Under ophthalmoscopic examination the retinal veins were engorged ; the margins of the disc hazy. On palpation there was a sense of resistance beneath the upper orbital margin, with doubtful deep fluctuation. There were no enlarged glands. The child was in pain, looked ill and thin, and was said to have lost flesh rapidly. The tongue was furred. Temperature $97 \cdot 8^{\circ}$; pulse 66 ; urine 1032 , acid, no albumen or sugar.

Aug. 27th.-The condition of the eye has scarcely altered, but there is more pain. No sickness since admission. The temperature has slowly risen, and remains about $100^{\circ}$. There is now a solid resistance to be felt at the lower and inner part of the orbit. Ether havin $\%$ been administered, an incision was made close to the lower orbital margin towards the nasal side. At a depth of an inch to an inch and a quarter thick fetid pus was discovered, and two to three drachms let out; a small area of rough bone was felt. A drainage-tube was inserted, and an iodoform dressing applied. Pus continued to drain away in small quantities for the next two days. The boy was much more comfortable. The temperature continued above normal.

30th.--More proptosis; discharge of pus continues.

Sept. 3rd.-Considerable chemosis of conjunctiva; eyeball greatly protruded. Ether again adninistered, and the

1 Diseases and Injuries of the Eye. 2 Medical News, April, 1888 3 Nettleship. 